\title{
All the Waters of Lethe: An Experience of Female Alcoholism in Federation Queensland
}

\author{
Alana Piper
}

Whether it is treated as an issue for consternation or celebration, a propensity for drunkenness has long been represented as an essential trait of the Australian character. The image of the Australian drinker has remained distinctly masculine, with drinking canonised as a male pastime by Russel Ward's The Australian Legend (Ward 1958: 2). While Australian histories of inebriation have recognised the gendered nature of alcohol use, they have assumed implicitly that because drinking typically has been considered a masculine prerogative, the primary significance of liquor consumption to gender studies lies in the role it played in the construction of masculine identity. The assumption has been that because women's drinking was not conducted on the same scale as men's, the excessive drinking indulged in by a minority of females is unimportant to larger understandings of femininity. This has inhibited investigation of female drunkenness, the responses it provoked and the critical expression of power relations constituted by these reactions.

This situation has been compounded, as with other areas of women's history, by difficulties in identifying fruitful sources for study. Usually only a few details can be discovered about historical women who battled problems with alcohol, so when fuller accounts can be unearthed this makes them all the more compelling. Annie Mabel Rodgers is exceptional in offering a rare tangible example of a middle-class female drinker from the turn of the twentieth century. An elucidation of her story demonstrates that, despite perceptions that drinking was largely a masculine vice, considerable anxiety did exist about female alcohol abuse in Queensland at the time of Federation. In particular, there was heightened concern that an increasing number of otherwise respectable housewives were secret drunkards. Analysing the events of Annie's life outlined in extensive archival material enables greater understanding, not only of Annie's experiences as an individual, but of general responses to female drunkenness in this era. As Annie Rodgers' case shows, the community's efforts to solve the problem of female drunkenness by using the institutions of marriage, medicine and the law as tools of reform remained largely unsuccessful. Therefore, Annie Mabel Rodgers' story of marital trouble, adultery, institutionalisation, imprisonment and blighted motherhood appears characteristic of the dominating themes in the lives of many female inebriates in Federation Queensland.

On 15 May 1902, Annie Mabel Rodgers wrote to her husband, Edward, regarding the divorce proceedings he had initiated against her on the grounds of 
drunkenness. Annie was living with family members in Brisbane; Edward had moved to Sydney with their son, Garde, three years earlier. The press considered this move a calculated ploy to enable Edward to avail himself of New South Wales' more liberal divorce legislation, which permitted habitual drunkenness as a cause for marriage dissolution, while Queensland law did not. In her letter, Annie proclaimed that to spare her son the shame of seeing his parents engaged in a public court battle, she was willing to drop her counter-petition and allow Edward to obtain his divorce quietly. Declaring her desire to start a new life, Annie entreated Edward to settle a sum of money on her that would enable her to do so. As she had done in a previous letter in February, Annie implored Edward to be good to Garde, and to remember her to him (Divorce file, no. 4169, SRNSW).

The letters were eventually entered into the court record as evidence that Annie did not intend to contest the proceedings. Preserved for posterity among the case's other depositions, these letters provide far more information than was needed for the court's purposes. As their tone alternates between defiance, despondence and desperation, the letters create an image of a complex, troubled young woman, whose narrative forcefully represents the perils of drunkenness for women in early twentieth century Australia. The May letter in particular provides a rare insight into how a female alcoholic in this period understood her own addiction, with Annie opining:

I've tried to buy oblivion but it is beyond my price. It seems to me that memory is the Devil, always coming in weak moments to drive one mad or to any excess. I think all the waters of Leathe [sic] would not suffice me.

Throughout Annie's story, it is never clear precisely why this middle-class wife sought the waters of Lethe, the river of forgetfulness, through alcoholic oblivion, although spousal cruelty, childhood environment and discontent with her social role are all possible explanations. Yet Annie is a rarity in the completeness with which her life can be traced through a rich variety of archival sources. Her letters offer an infrequent example of a first-hand account by a female alcoholic, whose life histories usually must be pieced together through the largely condemnatory commentary of men.

Historical analysis of Australian women's alcohol use has been somewhat limited, although inquiries by Diane Kirkby (2007), Tanja Luckins (2007) and Clare Wright (2003) have begun to reveal the importance of alcohol in women's social lives. However, Ross Fitzgerald's recent history of alcohol in Australia pointed out the amount of work still to be done on this issue, particularly on the subject of class (2009: 97-101). Although it is commonly assumed that traditional prohibitions against women's drinking meant that most historic female drunkards were women from the economic and social margins, considerable concern existed in the early twentieth century about the extent of female drunkenness amongst the middle class. In 1903, the prurient scandal-rag Truth deplored the increasing inebriety of Brisbane's women in particular:

That secret drinking among women of the better classes is becoming very common in Brisbane is a sad and solemn fact. Time was when the woman who drank, even in moderation, was far from common, while the intemperate woman, the woman who got drunk, who, in the privacy of her own home, went on prolonged drinking bouts, 
was a rarity. Now, alas! The former class is to be met with daily, while members of the latter are common. (31 May 1903)

An astonishing quantity of intoxicants was reportedly sold to 'fashionably dressed ladies' in refreshment rooms, and leading Brisbane cafés were accused of surreptitiously supplying spiked sodas and coffees to oblige their female customers (Truth, 26 July 1908). During the 1901 Royal Commission into the Queensland liquor industry, several witnesses also testified that they had personal knowledge of grocers illicitly selling single bottles of alcohol to housewives, a dodge supposedly well known to 'the better class of women', those who 'would never go to a public-house' (Queensland Royal Commission on Licensing and Liquor Laws 1901: 152, 735). The Commission noted that drinking among women seemed to be an increasing problem, especially in the capital. Local temperance tracts likewise preached that the 'jewelled women' of Brisbane had embarked on a path of self-destruction (Lucas 1894: 74). While the secret nature of this drinking makes the legitimacy of such assertions difficult to determine, Annie Rodgers embodies a concrete example of a middle-class female alcoholic.

Annie's father, Daniel Donovan, married her mother, Anne Fogarty, in 1859 and together they had several children. On her own marriage certificate and in her admission papers to the Dunwich Benevolent Asylum's inebriate institute, Annie listed her father's rank or occupation as 'gentleman' rather than 'publican'. Publicans occupied a nebulous position in Australian society: their ventures could be highly profitable, and a wealthy hotel owner had the opportunity to become a leading citizen; nevertheless, many continued theirs a vulgar occupation. Daniel Donovan's establishment, the White Horse Hotel, was considered an ornamental addition to Toowoomba, and was described as capacious and tastefully decorated (Brisbane Courier, 9 July 1866). Over the years, Daniel acquired other properties and achieved a common ambition of the middle-class publican by entering politics when he was elected to the Toowoomba Town Council in February 1865 (Brisbane Courier, 18 February 1865). Although Daniel was the subject of insolvency proceedings in 1868 , he later seems to have recovered his position (Insolvency File 1868, 1057240, QSA).

Perhaps the instability suggested by the insolvency proceedings affected Annie, who was born in 1874 , and it may have contributed to her problems later in life. Temperance advocates certainly would have ascribed her drunkenness to her father's profession, with the drink craving considered so infectious that it could be contracted by women through their mere presence in a bar (Queensland Royal Commission on Licensing and Liquor Laws 1901: 148). It would not have been unusual for Annie to have worked in the hotel or served alcohol alongside her mother and sisters. Temperance crusaders - who objected to the employment of barmaids - believed that such work exposed women to the temptations of alcohol as they were expected to accept drinks from customers so as to increase the bar's profits (Queensland Royal Commission on Licensing and Liquor Laws 1901: 101). However, Annie's alcohol dependency purportedly began after, and perhaps as a result of, her marriage.

Edward Rodgers, 29 years of age to Annie's 19 at the time of their marriage in 1893, met her while pursuing business interests in South-East Queensland. According to the account of their marriage given at the time of the divorce, he 
spent the following years operating various commercial ventures around Queensland, New Zealand and his native New South Wales. By 1902 he was employed in Sydney by the Australian Widows Life Assurance Society for a salary of $£ 400$ to $£ 500$ per annum. This was augmented by various investments, including a large banked sum and shares in a Western Australian gold mine.

Annie's marriage thus confirmed her status as part of the affluent middle class that valued sobriety and modest behaviour as a means of preserving bourgeois standing and attaining class mobility. If a middle-class woman did develop a penchant for drinking, concealment was necessary, as demonstrated by the ruse exposed to the Liquor Commission of housewives having alcohol entered down as other innocuous items on their grocer's bill. Annie's alcoholic condition might similarly have remained a family secret, or at least never become a matter of public record, if Edward had not sought a divorce. However, as a known drunkard, Annie became a topic of tabloid journalism, her scandalous behaviour given an added frisson by her family's social position. Truth commented snidely that the disgrace fell heavily upon her 'eminently respectable' people, and that it was lucky that 'her poor mother is dead and saved from this disgrace' and unfortunate that her father, 'an exceedingly gentlemanly-looking old man', was 'still in the flesh' (31 January 1904).

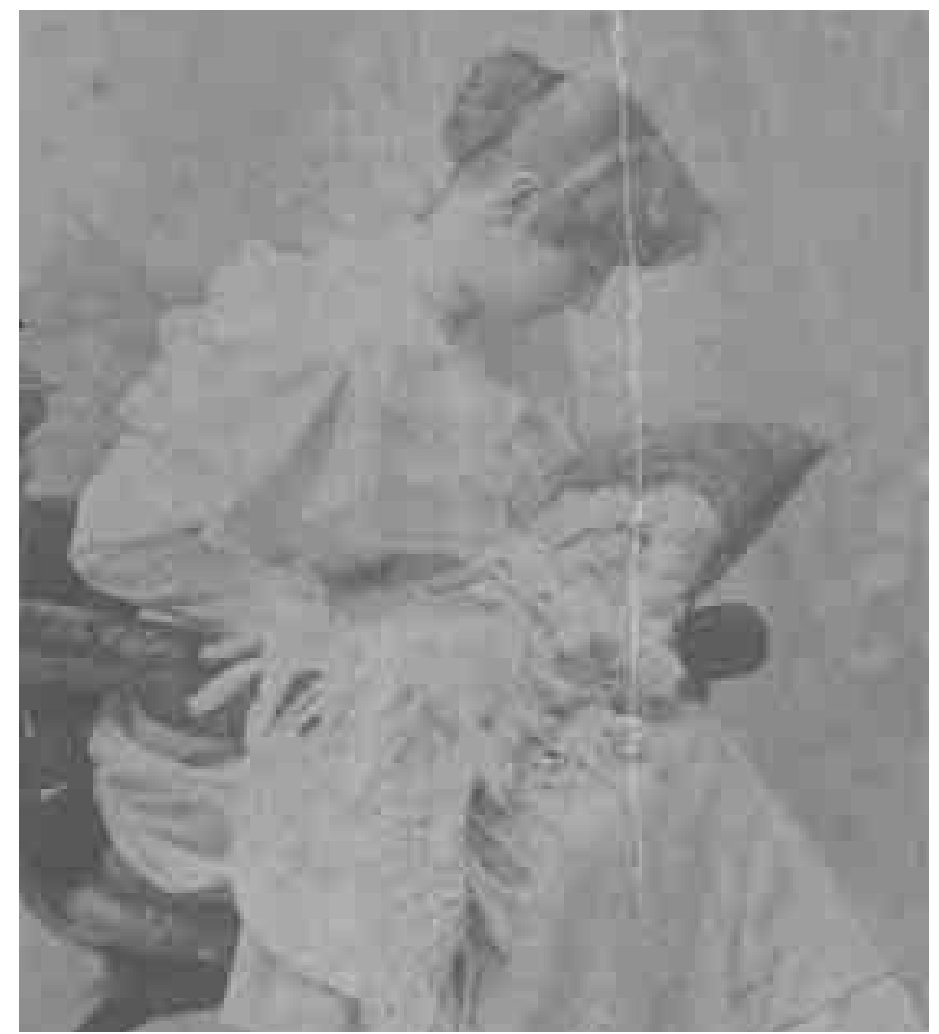

Photograph of Annie Rodgers and son Garthe c.1895. Taken from State Records NSW: NRS 13495, divorce and matrimonial cause papers, No 4169 of 1901, [13/12567] 
It is not known when Annie began drinking, only that in 1901 it had been for upwards of three years, the period required to initiate divorce proceedings. According to Truth, Annie's 'troubles' began shortly into marriage as a direct result of her husband's status as an urbane businessman. Frequent alcohol intake formed part of the hectic whirl of social engagements said to have developed her reliance on liquor, so that she was a 'confirmed drunkard' by the time of Garde's birth in 1895 (31 January 1904). It was not uncommon for the paper to blame women's drinking on the frivolous nature of the high-society lifestyle; the absence of household duties to meaningfully occupy women's time was believed to create a sense of ennui that some relieved with a secret alcohol habit (20 July 1902), while others relied on liquor to maintain them during a ceaseless 'round of gaieties' (18 November 1900). Prevailing medical opinion similarly decreed that some genteel women, unable to deal with the rigours of married life, turned to alcohol as a stimulant for their enervated state (Murray, in Jones 1912: 1711).

Female drunkenness was also sometimes ascribed in this period to the influence of nefarious men, particularly those who were racially or ethnically 'other'. In the press coverage of the couple's divorce, it therefore became significant that Edward was Jewish by birth. Australian colonies generally were tolerant of the Anglicised Jewish minorities that developed in their major cities, but a strain of antiSemitism continued to influence their media depictions. Truth implied a definite if mysterious connection between Annie's alcoholism and her marriage to a Jewish man, even though such inter-faith marriages were not uncommon in metropolitan areas, especially in Brisbane where Jewish males far outnumbered the females even by the turn of the century (Rubinstein 1987: 89). This was not the only time the newspaper blamed a Jewish man for an Anglo-Australian woman's drunkenness, although the usual ethnic targets in this respect were the Chinese. To Truth, Edward's wealth made him a suspicious character, probably due partly to the pervading stereotype of Jewish avarice and partly to the paper's general prejudice against the wealthier classes. Edward, as a 'man of the world, well-versed in its wiles and wickedness', was accused of first teaching Annie to drink in order to keep him company (31 January 1904).

Annie likewise appears to have blamed her husband for her drunken condition, reproaching in her May letter 'you only know what share or part you have in the present state of affairs'. In her initial counter-petition, Annie accused Edward of cruelty and desertion, and her declared need to use liquor to blot out bad memories - presumably of her marriage - seems implicitly to fault Edward's treatment of her. According to her counter-petition, Edward's cruelty allegedly consisted of both verbal and physical abuse. Annie claimed that she had been particularly pained by the discovery that Edward told people she was not his wife, but his mistress, in order to court other women. Possibly coldness and cruelty on Edward's side instigated Annie's alcohol dependence; it is equally possible that Edward's treatment of her represented an outraged response to his wife's behaviour.

If alcoholism formed the root cause of their marital strife, Edward presumably would have attempted to induce Annie to moderate or abandon her drinking. He probably tried to do so using the economic leverage that most husbands wielded over their wives; reports on domestic dramas that reached the courtroom during this period indicate that some spouses tried to curb their wives' drinking 
by refusing them money until the habit was broken (Truth, 1 February 1903; 19 February 1905). In Louis Stone's novel Jonah, first published in 1912, the eponymous hero likewise tried to stop his wife's drinking - which was represented as the result of her inability to adjust to her new middle-class position after growing up in a Sydney slum - by stopping her allowance (Stone 1988: 208).

Edward also may have resorted to more physically forceful measures, as the use of domestic violence to check female drunkenness was tacitly accepted and even encouraged. Kay Saunders exposed the public's ambivalent attitude towards the abuse of drunken wives in her 1984 article on domestic violence in colonial Queensland, which found that men who justified spousal assault as a response to their wife's alcohol use were rarely convicted by juries (Saunders 1984: 77-8). The assaults of which Annie accused Edward were possibly rationalised as 'necessary' in his mind by Annie's behaviour. The perceived role of husbands as superintendents of their wives' use of alcohol is illustrated by the comments made to the liquor commission by the Sheriff of Queensland who, when questioned as to the age children should be allowed to enter public houses, replied that women should be prohibited from such places 'until they are married, and their husbands can look after them' (Queensland Royal Commission on Licensing and Liquor Laws 1901: 743).

When women developed alcohol habits despite their husbands' scrutiny, men similarly were expected to break their wives of the dependency. Brisbane magistrate Robert Ranking declared disapprovingly to a husband who had deserted his drunken spouse: 'It's the man's duty to try and help his wife to reform.' (Truth, 1 February 1903) If Edward attempted to reform Annie, he must eventually have judged the effort futile, and during the later years of the marriage the couple led separate lives. While Edward conducted his business in New South Wales, Annie enjoyed extended visits to family in Queensland and Melbourne. Such holidays were possibly a convenient subterfuge to avoid each other's company while maintaining the outward appearance of middle-class respectability.

By June 1901, the couple was definitely living apart when events transpired that seem to have proved the ultimate catalyst in their divorce. A man named Hedley Havelock Tooth later signed a statutory declaration that during that month Annie, after taking a room in Hedley's home a week earlier, committed adultery with an unknown gentleman. According to Hedley, he discovered Annie in the sitting room with her 'back on the sofa ... her bare legs ... visible above the knees and a man ... lying on top ... having connection with her'. The man was thrown out of the house, coming back ten minutes later to claim the mackintosh he left behind during his hasty ejection. When Hedley asked Annie 'what she meant by such conduct', she replied that it was 'all right' as the man was an old friend. Hedley stated that he allowed Annie to remain in the house for the night because it was raining heavily and she had a cold, but evicted her the following day. After offering various facts to support the assertion that his lodger was the Annie Mabel Rodgers married to Edward Rodgers, Hedley testified that Annie was much addicted to drink, particularly spirits, but that 'when sober she was utter [sic] lady like'.

Accusations of female adultery were not uncommonly accompanied by claims that the woman was an alcoholic. Society's censorious attitude towards female 
drinking was predicated largely on the association between excessive drinking and permissive sexuality. The conviction that drunken women were capable of almost any recklessness was used by Truth to urge the need for amendments to Queensland's divorce laws, as it pronounced that 'a drunken wife is nearly always a wanton' (5 April 1903). Annie's adultery would have been read as a natural progression of her drunken habits, an apt illustration of the necessity of enabling husbands to divorce their drunken wives, who might otherwise contaminate the family home and stock. In the end, though, the adultery charge against Annie went unproved, with the magistrate simply granting the divorce on the grounds of Annie's drunkenness. Yet Truth made it clear that even if she had avoided stepping 'over the border line that separates virtue from moral degradation' during her marriage, such a calamity could not be prevented for long if Annie continued her drunken excesses. Such was the strength of belief in the connection between female alcohol consumption and sexual impropriety that the newspaper proclaimed with certainty that Annie would soon slip 'into the gulf of vice ... yawning at her feet' unless her family could effect her reformation (31 January 1904).

Annie's family had already taken steps to address her drinking problem in the months prior to her divorce. On 29 July 1901, a month after the alleged adultery, Daniel Donovan appeared before the Brisbane police court to submit an application for his daughter's removal to an inebriates' institution. That night her father was himself arrested for drunkenness in Edward Street, forfeiting a 5 shilling bail when he failed to appear in court the next day. Nevertheless, his application was approved and Annie was admitted to Dunwich (Deposition and Minute Book, 971030, QSA).

During the nineteenth century, alcoholism came to be viewed as a medical complaint, rather than a moral failing or criminal act. The campaign to establish special institutions where alcoholics could be medically treated, rather than confined to prisons or lunatic asylums, had been instigated in Australia in the 1860s (Garton 1987: 40-1). The movement gained momentum in the 1880s and 1890s as numerous private institutions were established across Britain, the United States and Australasia offering various 'cures' for alcoholism (Lewis 1992: 100-1). Following the passage of similar legislation in Victoria and New South Wales, community pressure led Queensland to establish the 1896 Inebriates Institutions Act to provide for the public care of inebriates. However, the colony was reluctant to expend money on new institutions, so in 1898 it was announced that the Dunwich Benevolent Asylum - already a dumping ground for many of Queensland's social outcasts - would thereafter also operate as an inebriates' institution (Patrick 1995: 260).

Annie was not the only middle-class woman to be committed to Dunwich for treatment during this period, with inebriate wives of businessmen, politicians and clergymen all shipped to the island for reformation. In chronic cases where hopes of rehabilitation had been given up, the institute provided a convenient place for respectable men to hide these awkward family members. Inebriates from the lower and even criminal classes were also sent to the institution, despite the protests of those who averred that separate facilities were necessary for alcoholic individuals of different ranks for the cure to take effect (Lewis 1992: 108). Retrospective historical analyses of Dunwich have concluded that the institute had 'no appreciable effect on the problem of alcoholism in Queensland' (Patrick 
1995: 260). 'Treatment' at the institute consisted merely of removal from temptation. Yet there is considerable evidence that, despite alcohol bans, inebriates were able to procure liquor from other inmates, staff members and visitors, or make their own concoction out of methylated spirits that came to be known as 'Dunwich lightning' (Goodall 1992: 86).

For Annie, Truth observed that the Dunwich experience proved 'worse than useless' (31 January 1904). The newspaper used Annie's story to illustrate the need for a proper, purpose-built asylum for inebriates, arguing that the institution's only effect on Annie had been to cause her to go on a 'howling spree' to celebrate her liberation. Release was undoubtedly a relief. Living conditions at Dunwich generally were regarded as deplorable, with some inmates declaring that prison life was preferable (Lewis 1992: 116-17). This was a comparison Annie would soon be in a position to make. Despite the magistrate's order that she remain at Dunwich for one year, Annie was discharged on 24 September 1901 to enable her to deal with her upcoming divorce (Female Admission Register, 9520, QSA).

Annie's counter-petition initially attempted to have Edward's case dismissed by claiming that Edward had not resided in New South Wales for the three-year period necessary for the couple's marriage to fall under the state's jurisdiction. If this ploy had been successful, Edward would have had to abandon his suit or pursue it in the Queensland courts, where the vague nature of the adultery evidence probably would have resulted in the case's dismissal. However, Annie's eventual decision to allow the divorce to proceed unopposed led the presiding judge to discount her counter-claims and grant the divorce on the grounds that the defendant had been a 'habitual drunkard for three years and upwards thereby rendering herself unfit to discharge her domestic duties'. Early twentieth-century newspaper commentary suggests that it was this neglect of 'domestic duties' that was perceived as the chief wrong-doing of women who drank, with articles fixating on the failure of female alcoholics to prepare their husbands' meals on time or maintain an orderly home (see Piper 2009: 26-7). The press expressed considerable sympathy for the husbands of drunken wives. While the wives of drunken husbands received sympathy from temperance workers, they were often ridiculed in newspapers like Truth as nags and figures of comedy. In contrast, husbands took on an almost heroic stature in articles portraying their patient suffering while 'tied to a dirty, drunken drab of a trollop' (Truth, 5 April 1903). It was condemned as a gross injustice that working-class men who could not afford the costs of divorce should be ruined by 'the possession of a drunken, degraded wife, who sells his goods for drink, prostitutes his name and herself, and breaks up home after home' (Truth, 25 October 1908).

Divorce expenses could prove prohibitive, not only to the working classes but to women, as Annie's case makes clear. Although Annie came from a monied background and had married a wealthy husband, like many women she had little or no property of her own. During their separation, Annie continued to be reliant on her husband as her main source of financial support. Her weekly allowance from Edward of $£ 110$ s provided Annie with money to live on, but it was not enough to cover the cost of retaining a lawyer to defend her side of the suit. Again Edward agreed to pay a certain amount towards these costs, aware that such payments could be ordered by the court. Annie's solicitor requested $£ 25$ to defend 
Annie's case and subpoena several witnesses from interstate locations to counter Edward's accusations of adultery and drunkenness, and prove his cruelty. Edward's lawyers responded that the petitioner was willing to pay $£ 15$ on behalf of his wife's costs, which they considered adequate given that the evidence against Annie meant 'it seemed unlikely the trial would be a lengthy one'. Follow-up correspondence reveals that even this reduced sum was never received, perhaps because Edward realised that Annie's frayed nerves meant she would be likely to surrender in the face of such setbacks, abandoning the counter-petition rather than subjecting herself to the strain of a drawn-out divorce.

Annie's dependent and harassed condition is exposed pathetically in two letters she wrote to Edward during February and May, both begging for money. In her February missive, Annie asserts that Edward actually owed her $£ 20$, having previously deprived her of that amount when he approached her one day at the Metropole and offered to bank the sum for her but then took it and placed it in his own name. Edward probably took the money rather than seeing it squandered by his wife in the hotel. If it was money he had given her or that she had saved from a housekeeping allowance, Edward doubtlessly felt morally and legally entitled to take it back and bank it in his own name, whatever he said to Annie about it at the time. Annie's failure to mention the incident in the second letter suggests that she had realised the pointlessness of this line of reasoning and had prudently decided to adopt a more tactful tone. By May, Annie's demand had dropped to 'a few pounds' to start afresh as she declared that 'though I will always have my ghosts I must try and live again'. Her appeals to Edward indicate a fraught situation, with her family perhaps wearing on her nerves. The move back to Brisbane during the divorce proceedings indicates that her family had offered support and protection but this may have only been grudgingly given. Annie told Edward she hoped 'to go out west away from my own people and all who know my story'. Perhaps she felt herself to be an object of patronage or contempt.

Annie's pleas for money ultimately failed. Although she wrote that she would 'anxiously' await Edward's reply, none ever came. Instead, on 19 May 1902 he used the letters as evidence that his wife did not intend to contest the suit and that her solicitor had no authority to defend the case. Edward stated he had not replied to the letters or communicated with Annie since proceedings started. In the last lines of her final letter to Edward, Annie indicated that the events of her marriage had convinced her that the marital state had few attractions for women, with the dependency it compelled heightening the perilous nature of such ventures. She declared her resolution of never remarrying, adding that in the future she would work for herself, the gentility of middle-class life in which women remained reliant upon their husbands apparently having lost its appeal.

For Annie, the divorce meant more than a loss of status and financial security. In his petition Edward requested sole custody of their six-year-old son, Garde. Although all female drunkards were abhorred, special contempt was reserved for alcoholic mothers. While the heavy drinking of men was rationalised as a necessary escape from the demands of family life, the ideology of self-sacrificing motherhood denied women's need for relief from similar frustrations. To welfare inspectors and others, maternal alcoholism presented a far more serious threat than paternal drunkenness, as women had the primary responsibility for their children's care and 
guidance. Then, as now, alcoholism did place children at risk. In 1907, one twoyear-old girl died from hunger when her mother locked her and her four-year-old brother inside their Spring Hill home while she went shopping in the city and was detained on a public drunkenness charge (Inquest, 348971, QSA). TP Lucas included similar local horror stories of the negligence of drunken mothers in his 1894 saga of Brisbane's apocalyptic annihilation, The Curse and Its Cure (Lucas 1894: 30). Even domestic violence was even more readily tolerated within the community in cases where husbands accused their wives of endangering their children through alcohol use (Saunders 1984: 77). When he instituted divorce proceedings, Edward would thus have been confident of securing guardianship of Garde, and he refused Annie visitation rights during their separation.

While Edward took the position that Annie had forfeited her maternal rights by her indecorous behaviour, Annie mysteriously insinuated that Edward had used some underhanded tactic to separate mother and child, writing in May: 'Remember I never gave him up to you. You and I know how you got him and I remember his last goodbye to me, perhaps you have forgotten.' Annie also averred that she would never relinquish her claim on Garde. She avowed that her decision not to contest the divorce was prompted by a desire to protect her child:

Even if I were to contest were I thinking of myself, I'd make myself notorious and you ridiculous by the make of evidence that my solicitors has in hand ... it is because it would be his mother in the divorce court and ever and ever the shame of both sides on him that I have decided not to contest. I will spare you much for him ...

Annie also seems to have wanted to protect Garde from the effect that her alcoholism might have on him, declaring that she did not wish to 'influence' him in any way.

Annie's letters offer a different perspective to the contemporaneous press portrayal of the alcoholic mother as a villainous, inhuman monster. Fearful lest her son should forget her, Annie asked Edward to always remember her to him and 'tell him his mother was a good woman'. She feared being replaced in her son's affections, jealously affirming that 'another woman may be your wife but no one can be his mother'. For Garde's sake, however, Annie hoped that Edward would continue to 'get on in life'. Her final request in her last letter was for news of Garde. Unfortunately, while Annie might not have abandoned Garde in her heart, the divorce ended any legal right she had to him. When the decree nisi was handed down in June 1902, Edward received sole and permanent custody of Garde. As Annie predicted, Edward quickly remarried following the declaration of the decree absolute in February 1903. The couple had at least one child, a daughter named Enid Rodgers, born in 1904. It is not known whether Edward continued to follow the events in the downward spiral of his former wife's life.

Institutionalised, divorced and declared an unfit mother by her twenty-eighth birthday, it might have been thought that there was nothing left for Annie to endure. Her husband and the medical profession had failed to control her drinking, but there remained one final institution that attempted to assert its authority in such cases: the law. Annie's reduced circumstances and loss of status meant that she was no longer subject to any constraints to conceal her habit, and her subsequent displays of intoxication between 1902 and 1913 led to frequent arrests for public drunkenness (Admission Registers, 17303, 2905, 2923, 2924, QSA). 
Annie's prison record lists her as a domestic servant which, contrary to the popular belief that female drunkards largely were prostitutes, represented the most common occupation for women imprisoned for public drunkenness in Brisbane during this era (Admission Registers, 17303, 2905, 2923, 2924, QSA). Sometimes Annie, or a friend or family member, was able to raise money to pay the court's fine as an alternative to imprisonment; more often, Annie was forced to serve her sentences - which ranged between six hours and three months - at the Valley Gaol and later the newly constructed female prison at Boggo Road.

When imprisoned for the last time on 6 February 1913, Annie had 48 previous convictions recorded against her. Repeat offending was not unusual amongst the women imprisoned for drunkenness in Brisbane, with some females achieving as many as 200 convictions. This rampant recidivism forced many to conclude that, as a tool of reformation, imprisonment was largely a pointless exercise when it came to habitual drunkards. Captain Pennefather, the Queensland ComptrollerGeneral of Prisons, pointed out the strain on the prison system brought about by the futile imprisoning of such women:

A great proportion of male offenders, and a still greater proportion of female offenders, are sent to prison for drunkenness and its attendant evils. It is a deplorable fact that many of the women who fall appear to be past redemption. Numbers of female offenders were sent back time after time during the year, several of whom had seventy or more previous convictions recorded against them. (Pennefather 1905: 27)

His observations of inebriates convinced Pennefather that drunkards required treatment in special facilities, a view he regularly promoted to the government in his reports. Prison conditions certainly seem unlikely to have been conducive to improvement in the physical condition or mental state of inebriates. Boggo Road's female inmates, 40 to 50 per cent of whom were imprisoned for drunkenness annually during this period, repeated the same grinding daily routine of mundane work fuelled by a monotonous menu of uninspiringly plain food. Conversation between prisoners was discouraged. When the women had completed their work as laundresses or seamstresses of government-issue garments, they were locked back in to their cells at five o'clock each night (Dawson and Wood 2005: 14-18). A female journalist who inspected the prison in 1904 declared that 'the dreadful tedium of such an existence must be well nigh maddening' (Truth, 31 March 1904).

Despite telling Edward that she would never marry again, in 1910 a marriage certificate was issued to Annie and Edward Robert Collie. If Annie had considered remarriage an opportunity to begin afresh, it seems she soon faltered in her resolutions. Only after February 1913 does Annie's name disappear from the prison register, suggesting that she abandoned drinking or at least mustered enough selfcontrol to avoid arrest for public inebriation. Perhaps this sudden transformation was effected by a renewed desire to be a mother again. In 1914 a daughter, Jean Isabella, was born to Annie and her new husband. Sadly, the child died in the same year. Nothing is known of Annie's life thereafter except that in 1930 she accused another woman of stealing her purse while she was sitting on a doorstep in Victoria Place, South Brisbane. The charge was dismissed when the woman proved that the purse was her own property and that she had been trying to help a shaky Annie 
steady herself (Brisbane Courier, 6 November 1930). This suggests that Annie was still, or again, drinking.

It is evident that anxiety existed in early twentieth-century Queensland about the supposed increase in drinking amongst middle-class women. Yet concrete examples of such women are scarce, rendering Annie's narrative all the more fascinating. Annie's story survives largely because, in her case, male support was withdrawn and her middle-class status lost. Her husband's desire to free himself of Annie produced the extremely informative divorce records, including the valuable letters from Annie herself. Truth, in which the identities of particular women usually remained anonymous when middle-class drinking was discussed, probably only referred to Annie by name because she lacked a significant male protector who might institute proceedings on her behalf. Annie's committal to Dunwich could indicate concern on the part of her father, but it can equally be interpreted as stemming from her family's desire to be free of this troubled relation. Her various imprisonments likewise signal her total loss of respectability following her divorce, with straitened circumstances leading her to public rather than private drunkenness.

While the level of detail with which Annie's story can be told may be rare, her narrative serves to demonstrate that female drunkenness offers a rich and hitherto largely unexplored field in Australian history. Ultimately, Annie's history reveals more about external responses to female alcohol abuse than Annie's own understanding of the affliction. Her tale shows that the traditional institutions of marriage, medicine and law failed to curb the problem of female drunkenness, leading to calls for still greater intervention and restraint. Social responses to female drunkenness in Queensland were characterised by an oppressive authoritarianism that imbued both private policing and official action, with women punished for their transgressive behaviour through personal violence, material deprivation and loss of liberty. Although Annie Rodgers offers an infrequent illustration of a middle-class female drinker, her intriguing tale of marital woe, accusations of immorality, institutionalisation, maternal loss and criminalisation is representative of the dominating and tragic themes in the lives of many female alcoholics during the Federation era.

\section{References}

Dawson, C and Wood, F 2005, Last Prison Standing: A Short History of Boggo Road's No. 2 Division 1903-1989, Boggo Road Gaol Historical Society, Brisbane.

Deposition and Minute Book, Court of Petty Sessions Brisbane, 24/6/1901-6/11/1901, item id 971030, Queensland State Archives.

Divorce file Edward Rodgers v Annie Mabel Rodgers, no. 4169 of 1901, NRS 13495, State Records New South Wales.

Female Admission Register for Dunwich Benevolent Asylum 1859-1906, item id 9529, Queensland State Archives.

Fitzgerald, R 2009, Under the Influence: A History of Alcohol in Australia, ABC Books, Sydney.

Garton, S 1987, 'Once a Drunkard, Always a Drunkard: Social Reform and the Problem of Habitual Drunkenness in Australia, 1880-1914,' Labour History 5: 43-64.

Goodall, JB 1992, 'Whom Nobody Owns: the Dunwich Benevolent Asylum, an Institutional Biography 1866-1946', unpublished PhD thesis, University of Queensland. 
Inquest Maude Wolfe, 237/07, item id 348971, Queensland State Archives.

Insolvency File Daniel Donovan, item id 1057240, Queensland State Archives.

Jones, WE 1912, 'Report of the Inspector of Inebriate Institutions for the Year ending 31st December, 1911', Victoria Votes and Proceedings, Government Printer, Melbourne.

Kirkby, D 2007, “Beer, Women and Grub”: Pubs, Food and the Industrial Working Class', in Dining on Turtles: Food Feasts and Drinking in History, eds D Kirkby and T Luckins, Palgrave Macmillan, Basingstoke, pp. 136-53.

Kirkby, D and Luckins, T 2006, “Winnies and Pats ... Brighten Our Pubs”: Transforming the Gendered Spatial Economy in the Australian Pub, 1920-1970', Journal of Australian Studies 87: 75-86.

Lewis, M 1992, A Rum State: Alcohol and State Policy in Australia, AGPS, Canberra.

Lucas, TP 1894, The Curse and Its Cure, Vol. 1, JH Reynolds, Brisbane.

Luckins, T 2007, 'Pigs, Hogs and Aussie Blokes: The Emergence of the Term "Six O'clock Swill”, History Australia 4.1: 8.1-8.17.

Patrick, R 1995, 'Health Administration 1860-1910', in People, Places and Policies: Aspects of Queensland Government Administration 1859-1920, eds K Cohen and K Wiltshire, University of Queensland Press, St Lucia, pp. 246-65.

Pennefather, C 1905, 'Report of the Comptroller-General of Prisons for 1903', Queensland Parliamentary Papers 1904-05, Vol. 2, Government Printer, Brisbane.

Piper, A 2009, “'Something Too Awful”: Female Drunkenness in Brisbane, 1901-1912', unpublished Honours thesis, University of Queensland.

Queensland Royal Commission on Licensing and Liquor Laws 1901, Report of the Royal Commission Appointed to Inquire into and Report upon the Administration of the Laws Regulating the Manufacture and Sale of Intoxicating Liquors in Queensland: Together with the Proceedings of the Commission, Minutes of Evidence and Appendices, Government Printer, Brisbane.

Register of Female Prisoners, Valley Gaol, January 1902-October 1903, item id 17303, Queensland State Archives.

Register of Female Prisoners, Brisbane Prison, 1903-1904, item id 2905, Queensland State Archives.

Register of Brisbane Prison Admission, Female, 1906-1912, item id 2923, Queensland State Archives.

Register of Brisbane Prison Admission, Female, 1912-1916, item id 2924, Queensland State Archives.

Rubinstein, H 1987, Chosen: The Jews in Australia, Allen \& Unwin, Sydney.

Saunders, K 1984, 'The Study of Domestic Violence in Colonial Queensland: Sources and Problems', Historical Studies 21: 68-84.

Stone, L 1988, Jonah, Angus \& Robertson, London.

Ward, R 1958, The Australian Legend, Oxford University Press, Melbourne.

Wright, C 2003, “Doing the Beans": Women, Community and Drinking in the Ladies' Lounge, 1925-1975', Journal of Australian Studies 76: 7-17. 